\title{
Phosphorus speciation and availability in intertidal sediments of a temperate estuary: relation to eutrophication and annual P-fluxes
}

\author{
J.P. Coelho ${ }^{a, *}$, M.R. Flindt ${ }^{\mathrm{b}}$, H.S. Jensen ${ }^{\mathrm{b}}$, A.I. Lillebø ${ }^{\mathrm{a}}$, M.A. Pardal ${ }^{\mathrm{a}}$ \\ ${ }^{a}$ IMAR (Institute of Marine Research), Department of Zoology, University of Coimbra, 3004-517 Coimbra, Portugal \\ ${ }^{\mathrm{b}}$ Biological Institute, University of Southern Denmark, Campusvej 55, DK-5230 Odense M, Denmark
}

Received 26 January 2004; accepted 1 July 2004

\begin{abstract}
For a better understanding of the phosphorus dynamics and bioavailability in temperate climates, sequential chemical extraction techniques were used to study sediment P-pools distribution and relative importance in a eutrophicated estuary.

Results indicate a shift in importance from the iron-bound $\mathrm{P}$ fraction to the $\mathrm{CaCO}_{3}$-bound $\mathrm{P}$ fraction with increasing salinity, which suggests a decrease in bioavailable $\mathrm{P}$ from the most inner part of the estuary seaward, as the $\mathrm{CaCO}_{3}$ associated $\mathrm{P}$ is believed to be less available for organisms. Salt marsh plants also influence sediment $\mathrm{P}$ speciation, through higher organic $\mathrm{P}$ fractions (mainly humic acid associated P) when compared to non-vegetated sediments. The ratio of iron-bound $\mathrm{P}$ to iron-oxyhydroxides may be used as an indicator of $\mathrm{P}$ availability, since it reflects the number of available $\mathrm{P}$ sorption sites in the metal oxides. This ratio was lowest in the intermediate zone of the estuary (13.7) when compared to the outer site (29.6) and the upper site (26.1), suggesting saturation of sorption sites. Co-incident with this, the intermediate site is characterized by the occurrence of macroalgal blooms during summer. In the present case, superficial sediments in the Mondego estuary do not show a clear seasonal trend, either in total amounts of exchangeable $\mathrm{P}$ or $\mathrm{P}$ speciation. Pools of exchangeable $\mathrm{P}$ in the surface sediment were $\sim 30$ times higher than the annual net-export of $\mathrm{P}\left(14\right.$ ton $_{\text {year }}{ }^{-1}$ ) from the estuary. The annual $\mathrm{P}$ release from the sediment appears diminutive in comparison with the pool-size. Management measures to reduce nutrient input into coastal water systems should therefore consider that phosphorus availability may persist as a result of sediment supply, even after reducing the external point sources.
\end{abstract}

(c) 2004 Elsevier Ltd. All rights reserved.

Keywords: phosphorus; sequential extraction; estuary; salt marsh; eutrophication

\section{Introduction}

Estuaries worldwide exhibit clear evidence of eutrophication as a result of nutrient loading of anthropogenic origin (Moutin et al., 1993; Marques et al., 1997; Gomez et al., 1999; Cardoso et al., 2002; Dolbeth et al., 2003). In general, two main sources contribute most to the nutrient status and budgets of estuaries: (a) loading from diffuse and point sources; and (b) internal loading

\footnotetext{
* Corresponding author.

E-mail address: jpcoelho@ci.uc.pt (J.P. Coelho).
}

originating from the sediments (Zwolsman, 1994; Paludan and Morris, 1999). Estuaries are the location of the biggest cities in the world, but at the same time they are highly productive ecosystems and function as nurseries for several fish, crustaceans and mollusc species with commercial interest. Estuarine processes are therefore of great interest both from a geochemical, recreational, economic and ecological point of view (Zwolsman, 1994).

Despite the threats of eutrophication that ultimately cause a shift in primary producers, with a loss of rooted vegetation, most temperate coastal waters still have, 
more or less endangered, Spartina marshes. In general, salt marshes are considered as efficient sinks for nutrients, and in Spartina maritima rhizosphere, sediment storage capacity (namely for phosphorus) is enhanced by sediment accretion and sediment oxidation (Adam, 1990; Chambers and Odum, 1990; Sánchez et al., 2000; Flindt et al., 2002).

In general, mudflats are known to be important $\mathrm{P}$ reservoirs able to supply the water column within the system and/or the plume zone. Like most temperate coastal systems, the Mondego estuary (Fig. 1) has Spartina maritima marshes and large areas of highly organic non-vegetated mudflats, with a net release of $\mathrm{P}$ by P-mineralisation and P-desorption. This system has a net release of 14 ton phosphate year ${ }^{-1}$ to adjacent coastal waters ( 1 ton enters the system, while 15 tons are exported) (Flindt et al., 1997; Lillebø et al., 2002), and phosphate concentrations in spring/summer are suitable for macroalgal blooms to occur (Pardal et al., 2000; Martins et al., 2002). The main nutrient supply to the south arm of the Mondego is the Pranto river, which flows through highly fertilized agricultural fields.
Previous studies focusing on $\mathrm{P}$ dynamics showed that mud flats colonised by Spartina marshes have higher adsorption capacity (Flindt et al., 2002), and that through primary production activity these macrophytes were able to control phosphate efflux from the sediment (Lillebø et al., 2002). Phosphorus cycling and bioavailability in estuaries depend upon $\mathrm{P}$ speciation (de Jonge and Villerius, 1989; Lebo, 1991; Paludan and Morris, 1999; Andrieux-Loyer and Aminot, 2001). Sequential chemical extraction techniques have been a useful tool to examine these processes (Psenner and Puckso, 1988; Ruttenberg, 1992; Jensen and Thamdrup, 1993), since the analysis of total sediment $P$ does not represent an accurate measurement of $P$ exchangeability and bioavailability for algal growth. Phosphate can be present in the form of iron, aluminium and calcium oxides or adsorbed on the surface of minerals and organic materials. The range of conditions such as salinity, $\mathrm{pH}$ or redox potential present in estuarine systems determines the relative importance of each fraction (de Jonge and Villerius, 1989; Lebo, 1991; Paludan and Morris, 1999).

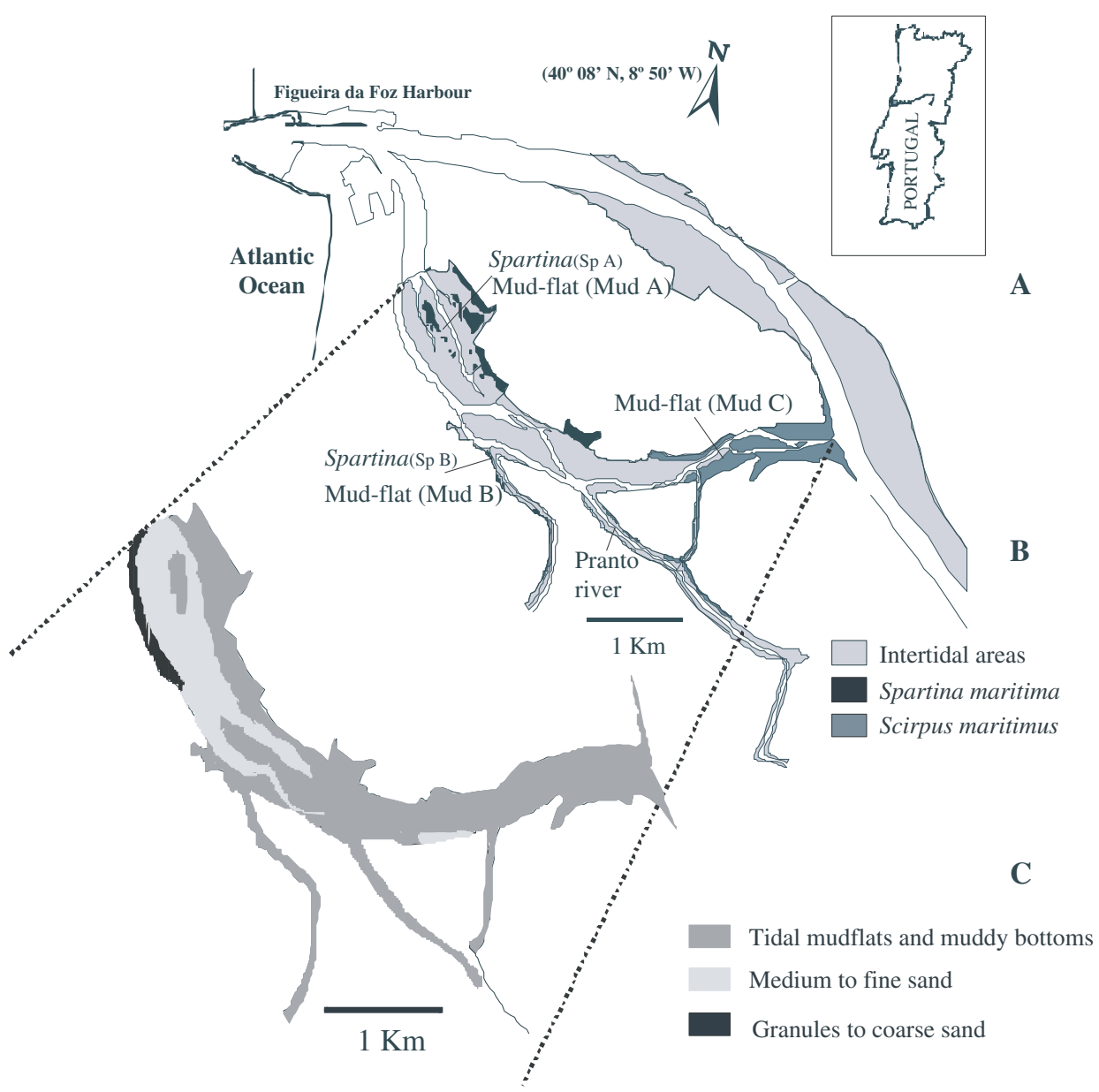

Fig. 1. (A) The location of the Mondego estuary, (B) the sampling areas in the south arm of the estuary; (C) representation of the sediment grain-size distribution in the south arm of the estuary (adapted from Cunha and Dinis, 2002). 
In order to achieve a better understanding of the $\mathrm{P}$ dynamics and bioavailability in temperate climates, the aims of this work were: (a) to quantify the relative importance of the distribution of $\mathrm{P}$ sediment fractions at representative estuarine sites and to elucidate their relative importance to the eutrophication process; (b) to analyse the effects of a Spartina maritima salt marsh on $\mathrm{P}$ speciation; (c) to study the seasonality of exchangeable $\mathrm{P}$ forms and compare it to the $\mathrm{P}$ seasonal dynamics in the water column of a well-documented eutrophic system.

\section{Materials and methods}

\subsection{Study site}

The Mondego estuary, located on the Atlantic coast of Portugal $\left(40^{\circ} 08 \mathrm{~N}, 8^{\circ} 50 \mathrm{~W}\right)$, is a warm-temperate system with large areas of intertidal flats (Fig. 1A). It is about $7 \mathrm{~km}$ long and is $2-3 \mathrm{~km}$ across at its widest part. The estuary comprises two contrasting arms, northern and southern, separated by an alluvium-formed island (Murraceira Island). The southern arm is shallower (2$4 \mathrm{~m}$ during high tide, tidal range $1-3 \mathrm{~m}$ ) and is almost silted up in the upper zones, so that the freshwater outflow is mainly via the northern arm. In the south arm, $75 \%$ of the intertidal area corresponds to mudflats. Spartina maritima salt marshes colonise $4 \%$ of the lower estuarine areas of the south arm, and is replaced by Scirpus maritimus in the most inner parts, following the salinity gradient, with spring high tide values ranging from 20 to 25 in the inner areas to 35 in the outer part. Five different areas (Spartina maritima salt marshes and unvegetated mudflats) were selected along a welldocumented eutrophication gradient (e.g. Marques et al., 1997; Pardal et al., 2000; Cardoso et al., 2002; Martins et al., 2002; Dolbeth et al., 2003) to represent the outer part of the estuary (Mud A and $\mathrm{Sp} \mathrm{A}$ ), an intermediate part (Mud B and Sp B) and the most inner mudflats (Mud C) (Fig. 1B). All sites correspond to deposition areas, and sediment grain-size distribution did not differ between sampling sites, mainly constituted by fine particles (organic matter, silt and clay) (Fig. 1C) (Cunha and Dinis, 2002).

\subsection{Sediment sampling}

At each site, three replicate sediment cores (plexiglas tubes, $3.5 \mathrm{~cm} \times 50 \mathrm{~cm}$ deep) were collected for sediment profile characterisation in July 2002. In addition, four $10 \mathrm{~cm}$ long PVC cores $(\varnothing=2.8 \mathrm{~cm})$ were sampled at each site in summer, late fall and winter 2002 for seasonal analysis of sediment. All cores were capped, placed on ice in an upright position and rapidly transported to the laboratory to be processed. The cores were sectioned under $\mathrm{N}_{2}$-atmosphere $(0.5$-cm sections in the top $\mathrm{cm}, 1-\mathrm{cm}$ sections from 1 to $3 \mathrm{~cm}$ depth, $2-\mathrm{cm}$ sections from 3 to $7 \mathrm{~cm}$, a $3-\mathrm{cm}$ section from 7 to $10 \mathrm{~cm}$ depth and $5-\mathrm{cm}$ sections from $10 \mathrm{~cm}$ downward). Sediments from the three replicate cores were pooled together to account for within site variability (Jensen and Thamdrup, 1993; Paludan and Morris, 1999). Sediment samples were homogenised and large plant material and macrofauna removed before freezing in sealed bags until analysis.

\subsection{Sequential extraction}

The sequential extraction consisted in a five-step process, modified after Jensen and Thamdrup (1993), in which the loosely adsorbed $\mathrm{P}$ fraction was extracted with $1 \mathrm{M} \mathrm{MgCl} 2$ instead of $0.46 \mathrm{M} \mathrm{NaCl}$ (Jensen et al., 1998) and the humic acid associated $\mathrm{P}$ fraction was isolated by filtration (Paludan and Jensen, 1995). The fractions considered were loosely sorbed $\mathrm{P}\left(\mathrm{MgCl}_{2}\right.$ extract), Fe-bound $\mathrm{P}$ (BD extract), Al/clay mineral bound $\mathrm{P}(\mathrm{NaOH}$ extract), humic acid associated $\mathrm{P}$ (humic acid fraction), Ca-bound $\mathrm{P}$ ( $\mathrm{HCl}$ extract), NRP (non reactive $\mathrm{P}$ from the $\mathrm{MgCl}_{2}$ and $\mathrm{NaOH}$ extracts) and refractory organic $\mathrm{P}$ (residual fraction). Iron that was extracted in the dithionite solution (termed BD-Fe) is considered to represent oxidized iron species able to bind phosphate (e.g. Jensen and Thamdrup, 1993). Parallel analyses of sediment total $\mathrm{P}$ and total $\mathrm{Fe}$ were performed to test the efficiency of the extraction method.

\section{Results}

\subsection{Sediment profiles and $P$ forms}

Only the top $20 \mathrm{~cm}$ of the sediment was analysed, since Spartina maritima roots ceased activity and downwards $\mathrm{P}$ concentrations and pool proportions were fairly constant. The depth profiles of the five sites show differences both in the amount and the proportion of the P pools (Fig. 2). Except for Mud C and Sp A sites, all sites had maximum concentrations of total $\mathrm{P}$ in the surface sediment (ranging from 15 to $27 \mu \mathrm{mol} \mathrm{Pg}$ $\mathrm{DW}^{-1}$ ). With increasing depth, $\mathrm{P}$ concentrations decreased, but differently depending on the site. In Mud C site, $\mathrm{P}$ content decreased progressively until $15 \mathrm{~cm}$ depth, where it becomes constant at very low $\mathrm{P}$ concentrations $\left(\sim 5 \mu \mathrm{mol} \mathrm{Pg} \mathrm{DW}{ }^{-1}\right)$. Sites Mud B and Sp B (the intermediate area of the estuary) have the highest $\mathrm{P}$ content at surface depth, which rapidly decreased in the top $2-3 \mathrm{~cm}$, after which stable values developed slowly and at much higher concentrations $(\sim 15 \mu \mathrm{mol} \mathrm{Pg}$ $\mathrm{DW}^{-1}$ ) than Mud $\mathrm{C}$ site. The sites nearer to the estuary mouth (Mud A and Sp A) exhibit a different pattern with a slow decrease from surface to $\sim 10 \mathrm{~cm}$ depth. 


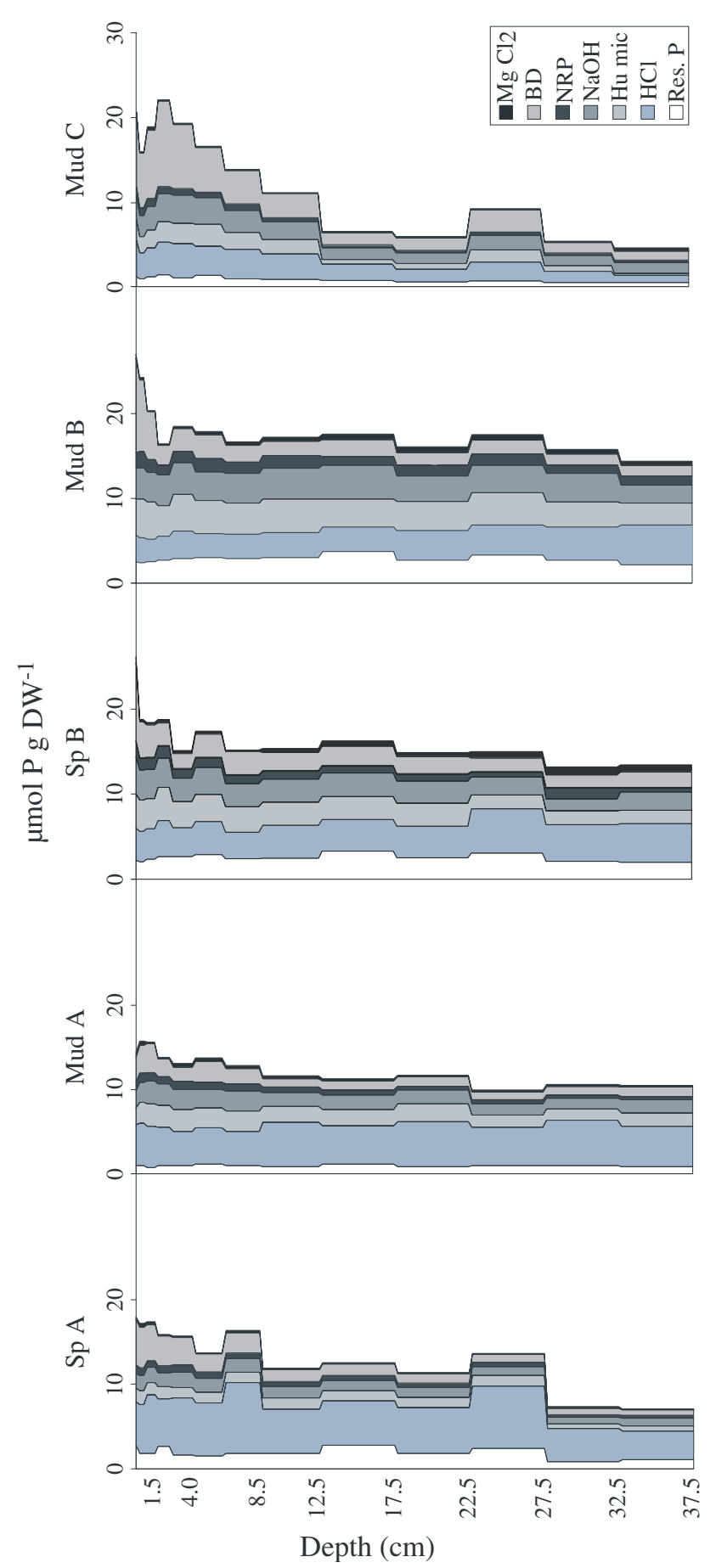

Fig. 2. Sediment depth profiles for extractable P pools at the Mondego sampling sites.

The characteristics of each sampling site in terms of $\mathrm{P}$ pool proportions are summarized in Table 1. Loosely adsorbed $\mathrm{P}$ represented the lowest $\mathrm{P}$ fraction, and showed little variation between sites. In Mud C site, iron-bound $\mathrm{P}(\mathrm{BD}-\mathrm{P})$ represented about a third of TP, clearly diverging from the rest, where this fraction made up about $15 \%$ of TP. B sites (both Mud and Sp) had the highest fraction of organic $\mathrm{P}$ (41 and $46 \%$ of TP, respectively), whereas Mud $\mathrm{C}$ had the lowest organic $\mathrm{P}$ content ( $\sim 25 \%$ of TP). The organic P content decreased with depth, probably due to continuous P-mineralisation in the deeper sediment layers. Vegetated sites showed higher organic $\mathrm{P}$ content than mud flats (Fig. 3), consistent with data from \%LOI (data not shown). Considering only the unvegetated sites, $\mathrm{P}$ associated with clays and aluminium oxides $(\mathrm{NaOH} P)$ decreased from the inner parts towards the mouth of the estuary. Vegetated sites had proportionally $\sim 5 \%$ more $\mathrm{P}$ in this fraction than unvegetated sites. The calciumbound $\mathrm{P}$ fraction increased with increasing marine influence, being the most important fraction in sites Mud A and Sp A with $\sim 40 \%$ of TP. The smaller HCl-P fractions, however, were observed in sites $\mathrm{B}$ in the intermediate area of the estuary, where it accounted for $\sim 16$ and $22.5 \%$ in Sp and Mud sites, respectively.

\subsection{Exchangeable $P$}

$\mathrm{P}$ concentrations were integrated with depth to obtain the total $\mathrm{P}$ mass in the sediment top $20 \mathrm{~cm}$ layer. To calculate the potential exchangeable $\mathrm{P}$ mass in the sediment, fractions $\mathrm{MgCl}_{2} \mathrm{P}, \mathrm{BD}-\mathrm{P}, \mathrm{NRP}$ and $\mathrm{NaOH} \mathrm{P}$ were plotted together, as the more refractory fractions are considered immobile and unavailable for organisms (Jensen and Thamdrup, 1993). Mud C was the site with the highest exchangeable $\mathrm{P}\left(\sim 1380 \mathrm{mmol} \mathrm{m}^{-2}\right)$, and a decrease was observed from the inner part to the outer part of the estuary with site $\mathrm{Sp} \mathrm{A}$ having the lowest exchangeable $\mathrm{P}$ mass $\left(\sim 800 \mathrm{mmol} \mathrm{m}^{-2}\right)$. Vegetated sites showed a tendency of less exchangeable $\mathrm{P}$ than nearby unvegetated sites, $\sim 40 \mathrm{mmol} \mathrm{m}^{-2}$ less in both cases (Fig. 4).

\subsection{Iron}

The total amount of iron per $\mathrm{m}^{2}$ of sediment was lowest in the intermediate area, with similar Fe masses present at the upper and lower reaches of the estuary. Vegetated sites had less iron than corresponding nonvegetated mudflats (Table 2). Molar, total Fe:total $\mathrm{P}$ ratio was always higher than 30 in superficial sediment and increased with depth at all sites. Regarding iron leached in the BD fraction, at all sites the maximum concentrations were observed in the top layers. Mud C had the highest proportion of BD-iron ( $\sim 15 \%$ of $\mathrm{TFe})$, while for the $\mathrm{B}$ sites only $\sim 4 \%$ of TFe were recovered in this fraction. Unvegetated sites showed higher BD-iron contents than correspondent vegetated sites (Table 2). The correlation coefficient for iron and $\mathrm{P}$ in the BD fraction of sediments $(n=12)$ was $r^{2}=0.925$ for Mud $\mathrm{A}, r^{2}=0.963$ for $\mathrm{Sp} \mathrm{A}, r^{2}=0.839$ for Mud B, $r^{2}=0.944$ for $\mathrm{Sp} \mathrm{B}$, and $r^{2}=0.892$ for Mud C. The $\mathrm{Fe}-\mathrm{P}$ ratio of the $\mathrm{B}$ sites was the lowest, in contrast with Mud A and C sites, suggesting saturation of free sorption sites on iron hydroxyoxide surfaces. Vegetated 
Table 1

Phosphorus forms ( $\%$ of total phosphorus) in the sediments of the Mondego estuary, Portugal

\begin{tabular}{|c|c|c|c|c|c|c|c|c|}
\hline & & \multicolumn{3}{|l|}{ Organic $\mathrm{P}$} & \multirow[t]{2}{*}{$\mathrm{Al} /$ clay $\mathrm{P}$} & \multirow[t]{2}{*}{$\mathrm{Ca}-\mathrm{P}$} & \multirow[t]{2}{*}{$\mathrm{Fe} / \mathrm{Mn} \mathrm{P}$} & \multirow[t]{2}{*}{ Exch. P } \\
\hline & & Refractory org. P & H.A. P & NRP & & & & \\
\hline Inner area & Mud C & 7.81 & 12.96 & 3.68 & 18.04 & 24.14 & 32.30 & 1.07 \\
\hline Intermediate area & $\begin{array}{l}\text { Mud B } \\
\text { Sp B }\end{array}$ & $\begin{array}{l}16.61 \\
17.35\end{array}$ & $\begin{array}{l}18.09 \\
21.21\end{array}$ & $\begin{array}{l}6.67 \\
7.49\end{array}$ & $\begin{array}{l}17.67 \\
20.52\end{array}$ & $\begin{array}{l}22.50 \\
16.27\end{array}$ & $\begin{array}{l}16.34 \\
14.83\end{array}$ & $\begin{array}{l}2.13 \\
2.32\end{array}$ \\
\hline Outer area & $\begin{array}{l}\text { Mud A } \\
\text { Sp A }\end{array}$ & $\begin{array}{r}14.88 \\
7.91\end{array}$ & $\begin{array}{r}9.27 \\
17.32\end{array}$ & $\begin{array}{l}3.92 \\
5.99\end{array}$ & $\begin{array}{l}10.66 \\
15.96\end{array}$ & $\begin{array}{l}43.18 \\
37.22\end{array}$ & $\begin{array}{l}16.68 \\
13.07\end{array}$ & $\begin{array}{l}1.41 \\
2.53\end{array}$ \\
\hline
\end{tabular}

sites had lower BD-Fe-BD-P ratios than unvegetated sites, due to a lower concentration of oxidized iron. The finding suggests that vegetated sediments are more reducing than non-vegetated sediments. When considering only the top two centimetres of sediment, however, salt marsh sites had higher BD-Fe:BD-P than mud flats (Table 2).

\subsection{Seasonality}

Seasonal variation of total exchangeable $\mathrm{P}$ in the sediment top layer $(5 \mathrm{~cm})$ was not significantly different (Kruskal-Wallis, $n=12,95 \%$ confidence level). A pattern with the amount of exchangeable $\mathrm{P} \mathrm{m}^{-2}$ diminishing seaward from the inner area of the estuary was observed though. For a depth of $0-5 \mathrm{~cm}$ the total exchangeable $P$ in summer, fall and winter was, respectively: 347, 281 and $299 \mathrm{mmol} \mathrm{m}^{-2}$ in Mud A; 253, 291 and $259 \mathrm{mmol} \mathrm{m}^{-2}$ in Sp A; 256, 384 and $397 \mathrm{mmol} \mathrm{m}^{-2}$ in Mud B; 285, 331 and $315 \mathrm{mmol} \mathrm{m}^{-2}$ in Sp B; and 384, 448 and $427 \mathrm{mmol} \mathrm{m}^{-2}$ in Mud C. Ironbound $\mathrm{P}$ seasonal masses also did not show significant

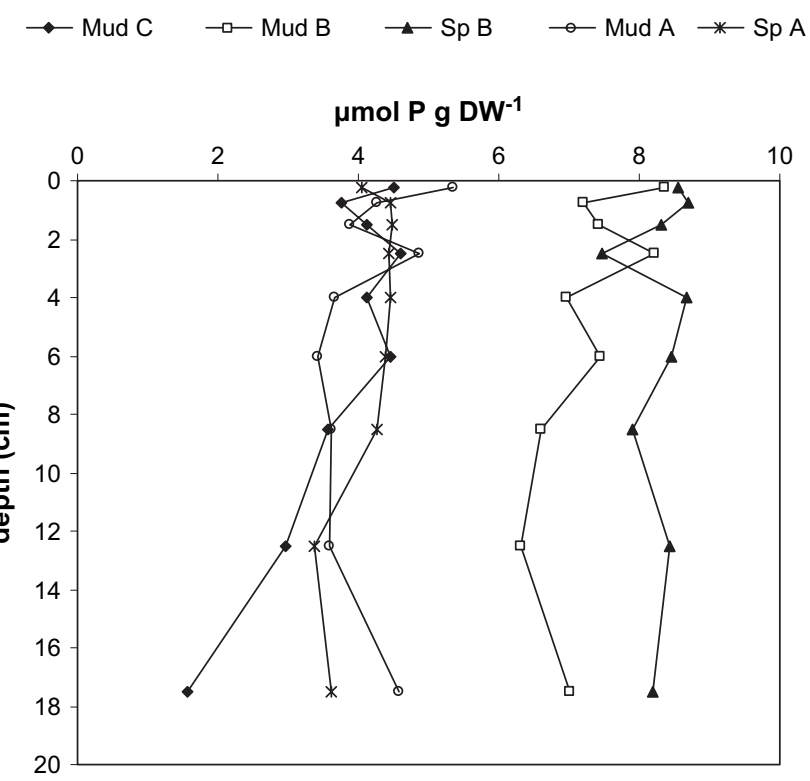

Fig. 3. Organic phosphorus (NRP, HA-P and Res.-P) profiles in the Mondego estuary. differences, despite a general trend of lower $\mathrm{P}$ mass in summer (Fig. 5). The decreasing trend of exchangeable $\mathrm{P}$ per area unit when moving seawards in the estuary concurs with the sediment profiles of solid-phase concentrations, supporting the idea of a shift in importance from the iron-bound $\mathrm{P}$ to the $\mathrm{CaCO}_{3}$ associated $\mathrm{P}$ pool with increasing salinities.

\section{Discussion}

Maximum values for extractable $\mathrm{P}$ pools occurred at surface layers and declined with depth to stable values, which is in agreement with observations in other estuarine systems (Jensen and Thamdrup, 1993; Moutin et al., 1993; Paludan and Morris, 1999). Labile fractions seemed to be responsible for these surface maxima, while more refractory pools dominated in deeper sediments.

In terms of $\mathrm{P}$ speciation, the upper part of the estuary, with the higher freshwater influence, was characterized by a dominance of iron-bound $\mathrm{P}$ and aluminium-bound $\mathrm{P}$ forms. Freshwater transport of phosphorus occurs mainly adsorbed to $\mathrm{Fe}$ and $\mathrm{Al}$ oxides (Lebo, 1991; Zwolsman, 1994), and this area was silted up, with low current velocities and longer residence time (Marques et al., 1993; Flindt et al., 1997) resulting in sedimentation of these phosphorus-rich particles.

@ total P $\mathrm{P}$ total exchangeable $\mathrm{P} \quad \mathbf{v}$ exch. P proportion

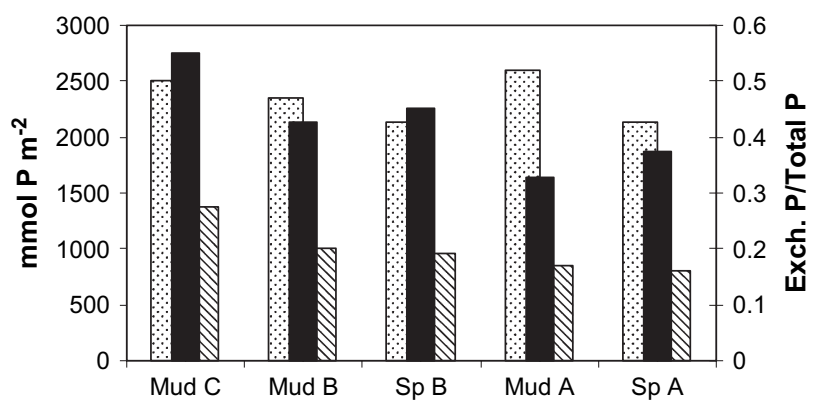

Fig. 4. Amounts and proportions of possibly exchangeable $\mathrm{P}$ (sum of $\mathrm{MgCl}_{2} \mathrm{P}, \mathrm{BD}-\mathrm{P}, \mathrm{NRP}$ and $\mathrm{NaOH} \mathrm{P}$ ) in the top $20 \mathrm{~cm}$ of sediment in the five sampling stations. 
Table 2

Sediment total $\mathrm{Fe}$, oxidized $\mathrm{Fe}$ (BD-Fe) and molar ratios of BD-Fe to BD-P

\begin{tabular}{lllll}
\hline & $\begin{array}{l}\text { Total Fe } \\
\left(\mathrm{mol} \mathrm{Fe} \mathrm{m}^{-2}\right)\end{array}$ & $\begin{array}{l}\text { BD-Fe } \\
\left(\mathrm{mol} \mathrm{Fe} \mathrm{m}^{-2}\right)\end{array}$ & BD-Fe:BD-P & $\begin{array}{l}\text { BD-Fe:BD-P } \\
\text { (top 2 cm })\end{array}$ \\
\hline Mud C & 76.32 & 11.25 & 26.10 & 17.81 \\
Mud B & 68.28 & 3.11 & 13.71 & 13.55 \\
Sp B & 56.25 & 1.98 & 10.74 & 17.45 \\
Mud A & 76.71 & 7.23 & 29.55 & 21.91 \\
Sp A & 72.15 & 3.81 & 25.66 & 24.43 \\
\hline
\end{tabular}

In the outer area of the estuary the fraction of ironbound $\mathrm{P}$ was lower, both when expressed on a dry weight basis and when calculated on a volume or area basis. This can result from several processes. First, the increase in $\mathrm{pH}$ with salinity increase may prevent phosphate adsorption onto iron-oxyhydroxides, by shifting the speciation of phosphate from $\mathrm{H}_{2} \mathrm{PO}_{4}{ }^{-}$to $\mathrm{HPO}_{4}{ }^{2-}$, and by changing the surface charge on the iron-oxyhydroxides (Lebo, 1991; Zwolsman, 1994). Also, the concentration of $\mathrm{Fe}$ oxides is reduced in sulphide environments by the formation of solid iron sulphides and if sulphate reduction rates are controlled by sulphate concentrations one can expect this rate to be highest at the seaward site (Krom and Berner, 1980; Paludan and Morris, 1999). Solid calcium carbonates are also influenced by salinity and $\mathrm{pH}$. Calcite is produced at high salinities through precipitation reactions and biological activity, both in estuarine and marine environments, forming an adsorption substrate for dissolved phosphate. Calcite transported upstream through tidal currents dissolves because of the lower $\mathrm{pH}$, releasing phosphate to the water column (de Jonge and Villerius, 1989). The present results are in agreement with this mechanism, as calcium-bound $\mathrm{P}$ is the most important fraction in the outer area of the estuary (sites A), whereas sites $\mathrm{C}$ and $\mathrm{B}$ through higher freshwater influence from the north arm of the Mondego and the Pranto river, respectively, have lower $\mathrm{Ca}-\mathrm{P}$ fractions. $\mathrm{CaCO}_{3}$ can therefore be considered an important pool in $\mathrm{P}$ dynamics not only in tropical areas but also in temperate estuaries, where it functions as a $\mathrm{P}$ immobi-

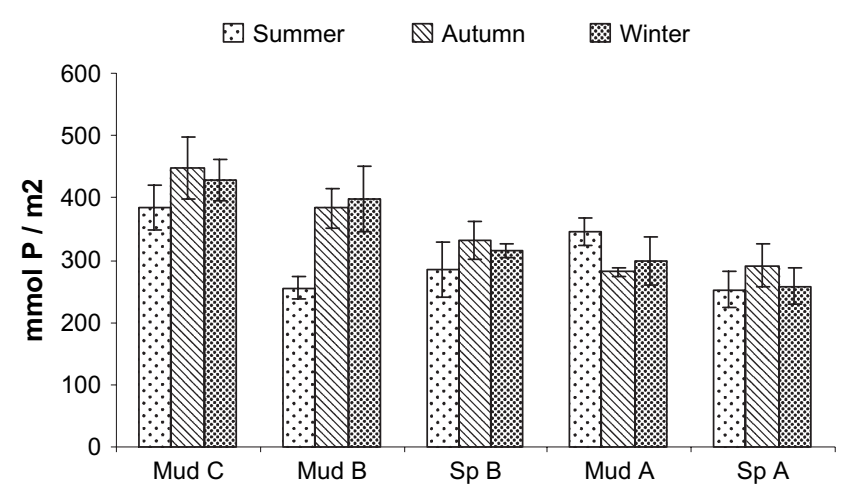

Fig. 5. Seasonal Fe-bound $\mathrm{P}$ masses for the five sampling sites. lization agent in the higher salinity area. Similar studies performed in various European systems have reported comparable Ca-bound $\mathrm{P}$ pools, supporting this idea (Moutin et al., 1993; Paludan and Morris, 1999; Andrieux-Loyer and Aminot, 2001). The intermediate area of the estuary is characterized by the highest proportion of organic $\mathrm{P}$, mainly humic acid associated $\mathrm{P}$. This high organic $\mathrm{P}$ content may be the result of flocculation and precipitation processes involving humic acids, $\mathrm{Fe} / \mathrm{Al}$ oxides and DRP complexes from advective mixing of saltwater with the nutrient rich freshwater input from the nearby Pranto river (Paludan and Jensen, 1995; Paludan and Morris, 1999).

The inner area of the estuary represents the largest sink of potentially exchangeable $\mathrm{P}$, tending to decrease seawards. This is reflected by the distribution of ironbound $\mathrm{P}$, the most important exchangeable $\mathrm{P}$ fraction (Jensen and Thamdrup, 1993). However, when only considering bare mud flats, our results suggest that the intermediate area is the most important in terms of Pdesorption and efflux, due to the lower Fe:P ratio in the $\mathrm{BD}$ fraction. The Fe:P ratio is considered to be a measure of free sorption sites for phosphate ions on iron hydrohydroxide surfaces (e.g. Jensen et al., 1992; Jensen and Thamdrup, 1993; Paludan and Jensen, 1995). The lower Fe:P ratios suggest saturation of sorption sites or less capability to adsorb phosphate, resulting in phosphate efflux to the overlying water. This may contribute to the occurrence of macroalgal blooms and severe eutrophic conditions especially in this intermediate area of the south arm, despite management efforts to reduce nutrient loading from freshwaters (e.g. Marques et al., 1997; Pardal et al., 2000; Martins et al., 2001).

Spartina maritima marshes strongly affected P speciation and bioavailability, causing less total $\mathrm{P}$, iron-bound $\mathrm{P}$ and potentially exchangeable $\mathrm{P}$, which may be related to plant uptake for growth purposes. Additionally, vegetated sites showed lower Fe:P ratios in the $\mathrm{BD}$ extract than unvegetated sites, suggesting that the vegetated sediments are more reducing. This may be due to a higher content of organic substrates, which is supported by the higher concentration of organic Pforms and the $\%$ of sediment loss on ignition (Lillebø et al., 2004, present data). The higher BD-Fe:BD-P of salt marsh sites when considering the top two centimetres of sediment, suggest an efficient aeration of the sediment. The ability to oxygenate the superficial layer of the sediment will create a barrier to $\mathrm{P}$ efflux from the sediment, as DRP generated in deeper sediment layers by $\mathrm{Fe}$ oxide reduction and mineralisation diffusing upwards will bind with Fe (III) in the oxidized layer. The Fe (III) layer at the sediment surface acts as a sink for DRP and inhibits the diffusion of porewater DRP out of the sediment (Chambers and Odum, 1990; De Groot and Fabre, 1993). This methodology reinforces previous results showing an enhanced efflux of phosphate in 
Spartina may marshes during the night (Lillebø et al., 2002) by revealing the mechanism through which primary production of Spartina marshes control the efflux of phosphate from the sediment.

Sediment seasonality studies revealed no differences in potentially exchangeable $\mathrm{P}$ fractions over the three seasons. A trend was visible for the iron-bound $\mathrm{P}$ pool, however, with lower masses in summer. These results may be a function of anoxia caused by excessive algal growth, which could induce the reduction of iron oxides and subsequent phosphate release. Comparing the pool-size of exchangeable $\mathrm{P}$ in the surface sediments (250-450 $\mathrm{mmol} \mathrm{m}^{-2}$ ) with vertical P-fluxes (Lillebø et al., 2004) of $40-80 \mathrm{mmol} \mathrm{m}^{-2} \mathrm{yr}^{-1}$ it is difficult to trace seasonal variation in the sediment pools even with a higher number of replicate samples than used here. The time consumption of the sequential extraction procedure simply limits the possible number of replicates.

The present results suggest that this system has a high sediment buffering capacity, and calculations based on the estuary area and the exchangeable $\mathrm{P}$ masses obtained indicate that if the $\mathrm{P}$ budget of the Mondego intertidal sediments (a net release of 14 tons per year) is maintained, the system can sustain the net-export of $P$ for almost 30 years before $\mathrm{P}$ depletion. The knowledge acquired is of crucial importance for management solutions, as efforts to reduce eutrophication in aquatic systems should consider the internal sources, despite a reduction of external loading. In these eutrophic systems phosphorus availability may persist as a result of sediment supply, even after reducing the external point sources.

\section{Acknowledgements}

This study was carried out in the scope of the research project DYNAMOD (POCTI/M6S137431/ 2001) funded by the Portuguese FCT and supported by The Danish National Science Foundation through a grant number 21020463 .

\section{References}

Adam, P., 1990. Plants and salinity in saltmarsh ecology. Cambridge University Press, pp. 208-277.

Andrieux-Loyer, F., Aminot, A., 2001. Phosphorus forms related to sediment grain size and geochemical characteristics in French coastal areas. Estuarine, Coastal and Shelf Science 52, 617-629.

Cardoso, P.G., Lillebø, A.I., Pardal, M.A., Ferreira, S.M., Marques, J.C., 2002. The effect of different primary producers on Hydrobia ulvae population dynamics: a case study in a temperate intertidal estuary. Journal of Experimental Marine Biology and Ecology 277, $173-195$.
Chambers, R.M., Odum, W.E., 1990. Porewater oxidation, dissolved phosphate and the iron curtain. Iron-phosphate relations in tidal freshwater marshes. Biogeochemistry 10, 37-52.

Cunha, P.P., Dinis, J.L., 2002. Sedimentary dynamics of the Mondego estuary. In: Pardal, M.A., Marques, J.C., Graça, M.A. (Eds.), Aquatic Ecology of the Mondego River Basin. Global Importance of Local Experience. Imprensa da Universidade de Coimbra, Coimbra, pp. 257-272.

De Groot, C., Fabre, A., 1993. The impact of dessecation of a freshwater marsh (Garcines Nord, Camargue, France) on sediment-water-vegetation interactions. Hydrobiologia 252, 105-116.

Dolbeth, M., Pardal, M.A., Lillebø, A.I., Azeiteiro U., Marques J.C., 2003. Short term and long term effects of eutrophication on the secondary production of an intertidal macrobenthic community. Marine Biology 143, 1229-1238.

Flindt, M.R., Kamp-Nielsen, L., Marques, J.C., Pardal, M.A., Bocci, M., Bendoricho, G., Nielsen, S.N., Jorgensen, S.E., 1997. Description of the three shallow estuaries: Mondego river (Portugal), Roskilde Fjord (Denmark) and the Lagoon of Venice (Italy). Ecological Modelling 102, 17-31.

Flindt, M.R., Pardal, M.A., Lillebø, A.I., Martins, I., Oliveira, J.M., 2002. Nutrient dynamics in the intertidal pools of the Mondego estuary. I - Nutrients sources, sediment profiles mineralisation and adsorption dynamics. In: Pardal, M.A., Marques, J.C., Graça, M.A. (Eds.), Aquatic Ecology of the Mondego River Basin. Global Importance of Local Experience. Imprensa da Universidade de Coimbra, Coimbra, pp. 257-272.

Gomez, E., Durillon, C., Rofes, G., Picot, B., 1999. Phosphate adsorption and release from sediments of brackish lagoons: $\mathrm{pH}, \mathrm{O}_{2}$ and loading influence. Water Research 33, 2437-2447.

Jensen, H.S., Kristensen, P., Jeppesen, E., Skytthe, A., 1992. Iron:phosphorus ratio in surface sediment as an indicator of phosphate release from aerobic sediments in shallow lakes. Hydrobiologia 235/236, 731-743.

Jensen, H.S., Thamdrup, B., 1993. Iron-bound phosphorus in marine sediments as measured by bicarbonate-dithionite extraction. Hydrobiologia 253, 47-59.

Jensen, H.S., McGlathery, K.J., Marino, R., Howarth, R.W., 1998. Forms and availability of sediment phosphorus in carbonate sand of Bermuda seagrass beds. Limnology and Oceanography 43, 799-810.

de Jonge, V.N., Villerius, L.A., 1989. Possible role of carbonate dissolution in estuarine phosphate dynamics. Limnology and Oceanography 34, 332-340.

Krom, M.D., Berner, R.A., 1980. Adsorption of phosphate in anoxic marine sediments. Limnology and Oceanography 25, 797-806.

Lebo, M.E., 1991. Particle-bound phosphorus along an urbanized coastal plain estuary. Marine Chemistry 34, 225-246.

Lillebø, A.I., Flindt, M.R., Pardal, M.A., Martins, I., Neto, J.M., Marques, J.C., 2002. Nutrient dynamics in the intertidal pools of the Mondego estuary. II - Seasonal efflux of $\mathrm{PO}_{4}-\mathrm{P}$ and $\mathrm{NH}_{4}-\mathrm{N}$ in bare bottom and vegetated pools. In: Pardal, M.A., Marques, J.C., Graça, M.A. (Eds.), Aquatic Ecology of the Mondego River Basin. Global Importance of Local Experience. Imprensa da Universidade de Coimbra, Coimbra, pp. 257-272.

Lillebø, A.I., Neto, J.M., Flindt, M.R., Marques, J.C., Pardal, M.A., 2004. Phosphorous dynamics in a temperate intertidal estuary. Estuarine, Coastal and Shelf Science 61, 101-109.

Marques, J.C., Maranhão, P., Pardal, M.A., 1993. Human impact assessment on the subtidal macrobenthic community structure in the Mondego estuary (Western Portugal). Estuarine, Coastal and Shelf Science 37, 403-419.

Marques, J.C., Pardal, M.A., Nielsen, S.N., Jorgensen, S.E., 1997. Analysis of the properties of exergy and biodiversity along an estuarine gradient of eutrophication. Ecological Modelling 62, 155-167.

Martins, I., Pardal, M.A., Lillebø, A.I., Flindt, M.R., Marques, J.C., 2001. Hydrodynamics as a major factor controlling the occurrence 
of green macroalgal blooms in an eutrophic estuary. A case study on the influence of precipitation and river management. Estuarine, Coastal and Shelf Science 52, 165-177.

Martins, I., Flindt, M.R., Pardal, M.A., Lillebø, A.I., Oliveira, J.M., Marques, J.C., 2002. Nutrient dynamics in the intertidal pools of the Mondego estuary. III - The importance of nutrient effluxes to macroalgal growth (Enteromorpha sp.). In: Pardal, M.A., Marques, J.C., Graça, M.A. (Eds.), Aquatic Ecology of the Mondego River Basin. Global Importance of Local Experience. Imprensa da Universidade de Coimbra, Coimbra, pp. 257-272.

Moutin, T., Picot, B., Ximenes, M.C., Bontoux, J., 1993. Seasonal variations of $\mathrm{P}$ compounds and their concentrations in two coastal lagoons (Herault, France). Hydrobiologia 252, 45-59.

Paludan, C., Jensen, H.S., 1995. Sequential extraction of phosphorus in freshwater wetland and lake sediment: significance of humic acids. Wetlands 15, 365-373.

Paludan, C., Morris, J.T., 1999. Distribution and speciation of phosphorus along a salinity gradient in intertidal marsh sediments. Biogeochemistry 45, 197-221.
Pardal, M.A., Marques, J.C., Metelo, I., Lillebø, A.I., Flindt, M.R., 2000. Impact of eutrophication on the life cycle, population dynamics and production of Amphitoe valida (Amphipoda) along an estuarine spatial gradient (Mondego estuary, Portugal). Marine Ecology Progress Series 196, 207-219.

Psenner, R., Puckso, R., 1988. Phosphorus fractionation: advantages and limits of the method for the study of sediment $\mathrm{P}$ origins and interactions. Archiv für Hydrobiologie - Advances in Limnology $30,43-59$.

Ruttenberg, K.C., 1992. Development of a sequential extraction method for different forms of phosphorus in marine sediments. Limnology and Oceanography 37, 1460-1482.

Sánchez, J.M., SanLeon, D.G., Izco, J., 2000. Primary colonization of mudflat estuaries by Spartina maritima (Curtis) Fernald in Northwest Spain: vegetation structure and sediment accretion. Aquatic Botany 69, 15-25.

Zwolsman, J.J.G., 1994. Seasonal variability and biogeochemistry of phosphorus in the Scheldt Estuary, South-west Netherlands. Estuarine, Coastal and Shelf Science 39, 227-248. 